\title{
HYPERSPECTRAL AND GEOCHEMICAL SIGNATURES STUDY ON LATE ARCHEAEN OF INDIAN HIGH GRADE MANGANESE DEPOSITS IN HALEKAL BAND OF BHAHADDURGHATTA-HOSAHATTY VILLAGE, CHITRADURGA SCHIST BELT (CSB), KARNATAKA, INDIA
}

\author{
Basavarajappa H.T ${ }^{1}$ and Manjunatha M.C ${ }^{2}$ \\ ${ }^{1}$ Department of Studies in Earth Science, Centre for Advanced Studies in Precambrian Geology, \\ University of Mysore, Manasagangothri, Mysuru-570 006, India \\ ${ }^{2}$ Department of Civil Engineering, Maharaja Institute of Technology, Thandavapura, Mysuru-571302, India
}

D.O.I - 10.51201/JUSST/21/05177

http://doi.org/10.51201/JUSST/21/05177

\begin{abstract}
Manganese is one of the most widely distributed elements in the earth's crust and mapping of these deposit are of high economic interest. Manganese occurs as diverse genetic types that is vital for iron and steel production. It occurs usually in the form of oxide, hydroxide, carbonate and silicate which is an important raw material for iron, steel industry, chief manufacturer of chemicals and dry cells in the form of manganese dioxides. Advanced analysis of hyperspectral signatures and GPS applications have opened a newest approach in exploration and systematic mapping of economic ore deposits. The present study aims to integrate the hyperspectral signatures with major elements of manganese ore deposits of Halekal band in Bhahaddurghatta-Hosahatty village of Chitradurga Schist Belt. The samples collected from field are studied in the laboratory using thin and polished sections under microscope and X-Ray Diffraction (XRD) analysis. Efforts are created to assess the spectral signatures of four representative random ore samples collected and analyzed through ASD Spectro-radiometer instrument operative in Visible and InfraRed (325 to $2500 \mathrm{~nm}$ ) region with concentration of major elements. This study clearly demonstrated and documented the spectral absorption features of the selected rock samples in the study area mainly depend on the optical and physico-chemical characters of the rock and major elemental composition as well as mineral constituents of the samples.
\end{abstract}

Keywords: Manganese; Geochemistry; Spectral signatures; Halekal Band; Bhahaddurghatta-Hosahatty.

\section{INTRODUCTION}

Manganese deposits of Archean age are found to occur in parts of Orissa, Andhra Pradesh and Karnataka (Mihir Deb and Gurmeet Kaur, xx). Karnataka hosts the largest recoverable reserves of manganese ore in the country that occurs in the stratigraphic level of the Chitradurga Group of Dharwar Super Group. The deposits of manganese ore are mainly found in Sandur Schist Belt, Shimoga Schist Belt, Chitradurga Schist Belt and North Kanara Schist Belt (GSI, 1981). They are stratiform, tabular, lenticular, patchy or pockety deposits of varying dimensions (IBM, 2014). Psilomelane, pyrolusite, cryptomelane and wad are the major minerals of manganese ore (IBM, 2014; GSI, 1981). The commercially viable manganese ores are mainly mixtures of pyrolusite and psilomelane. The chief rock types encountered in the schist belt areas where manganese ore occurs are metabasalt, meta greywacke and argillite, quartzite and limestone with laterite cappings (GSI, 1981). Banded iron formations with manganese are interbedded invariably with argillite and at times follow the carbonate band (GSI, 1981). A reserve of 11.89 million tonnes has been estimated with grades varying between $25 \%$ and $45 \%$ manganese in Chitradurga district and about 1.75 million tonnes in Tumkur district (GSI, 1981). Mn oxide ores, interstratified with chert and phyllite and closely associated with stromatolitic limestone, occur in Chitradurga-Tumkuru region (Mihir Deb and Gurmeet Kaur, xx). These Chitradurga Group strata are believed to have developed on the shallow platform margins about 2.6 Ga ago (Mihir Deb and Gurmeet Kaur, xx; Roy, 1981). 
The limestone-dolomite unit is overlain by the manganeferous members which includes banded manganeferous chert and manganeferous phyllite. This unit is stratigraphically significant, because manganese is typically absent in Bababudan group (GSI, 1981). Generally, the dolomite in its upper part becomes manganeferous and followed by the banded chert, which consists of alternate beds of pure chert, manganese and impure chert. This is overlain by the manganeferous phyllite. Wherever the chert is brecciated manganese di oxide ores fill the fractures (GSI, 1981). In the Chitradurga schist belt manganiferous formations are traceable discontinuously over a strike length of $180 \mathrm{~km}$ from Doddaguni in the south to Kandavada in the north (IBM, 2014). Bheemasamudra, Hulikatte, Keshapur, Ghattihosahalli, Hirekandavadi, Sadarhalli, Madadkere, Hosdurga, Huliyar, Chiknayakanahalli, Dodbylakere, Kanchipura, Chikbylakere, Sirankatte, Sivagange, Chikkandavadi, Honnebagi, Narsihalli, Sondenhalli, Karekurchi, Janchar, Halyal, Dodguni, Kondli and Shivasamudra are the places where manganese deposits are seen (GSI, 1981). The manganese ores are stratigraphically confined to an interbedded sequence of argillite and meta cherts overlying the conglomerate, orthoquartzite, basic volcanics with banded iron formation at top. These confine to lower stratigraphic horizon (Vanivilas Formation) of Chitradurga Group (GSI, 1981).

The ore deposit is secondary supergene enrichment over the poorly concentrated protores occurring at different levels within the sequence of phyllite and chert (GSI, 1981). The protore is of syngenetic type formed with the host rocks. The ore minerals are psilomelane, pyrolusite, cryptomelane and wad with iron, clay and quartz as gangue minerals (GSI, 1981). Mainly regional assessment of manganese ore deposits was attempted by GSI. Very few blocks were taken up for large scale mapping. The data generated is from the mines in operation and almost the entire area is leased to private parties. Occur in metallic form as oxide, hydroxide, carbonate and silicate. Important raw material in iron and steel industry (GSI, 1981). Ores are found to be interstratified with chert and phyllite and closely associated with stromatolitic limestone. Field and petrographic study suggests that these rocks are fissure filling type, wherever the chert is brecciated. Ore is of syngenetic sedimentary type, undergone supergene enrichment (GSI, 1981). Manganese ore is of magmatic type, where ores have undergone supergene enrichment type of volcanogenic origin which is simple with ore showing pyrolusite and cryptomelane textures (GSI, 1981). Wad colloform and replacement textures are common (GSI, 1981). These rocks are traced from Dodguni to Bhima Samudra along the western margin, over Sirankatte Gneiss on eastern limb of Kandavadi antiform and in Halekal band (GSI, 1981). Spectral reflectance is an optical property of materials that describes highlight in a continuous electromagnetic spectrum interacts with the material (Ali M.Qaid, 2008; Jeevan, 2018). The reflectance spectrum of manganese depends on the presence of major minerals composition of its surface mainly pyrolusite, psilomelane and weathering minerals (Rajendran et al, 2013a). Massive manganese occurrence is a mixture of several minerals, usually with pyrolusite and psilomelane.

\section{METHODOLOGY}

2.1 Study area: Study area covers an area of $1.23 \mathrm{~km}^{2}$ in between $76^{0} 05^{\prime} 76^{0} 10^{\prime} \mathrm{E}$ and $14^{0} 22^{\prime}$ to $14^{0} 27^{\prime}$ at central part of Halekal band near Hosahatty village. The ore bodies here are small in size, rarely exceeding $50 \mathrm{~m}$ in length and with widths between 3 and $5 \mathrm{~m}$ with shallow depth persistence (GSI, 1981). The area falls as Northern extension of a low hill range, extending North South direction. The ore body forms a part of North-Eastern margin of the Chitradurga 
schist belt generally following soil cover at the top, Banded Ferruginous Chert (BFC) at the middle and Manganese ore body/ dolomite at the bottom as geological succession (GSI, 1981).

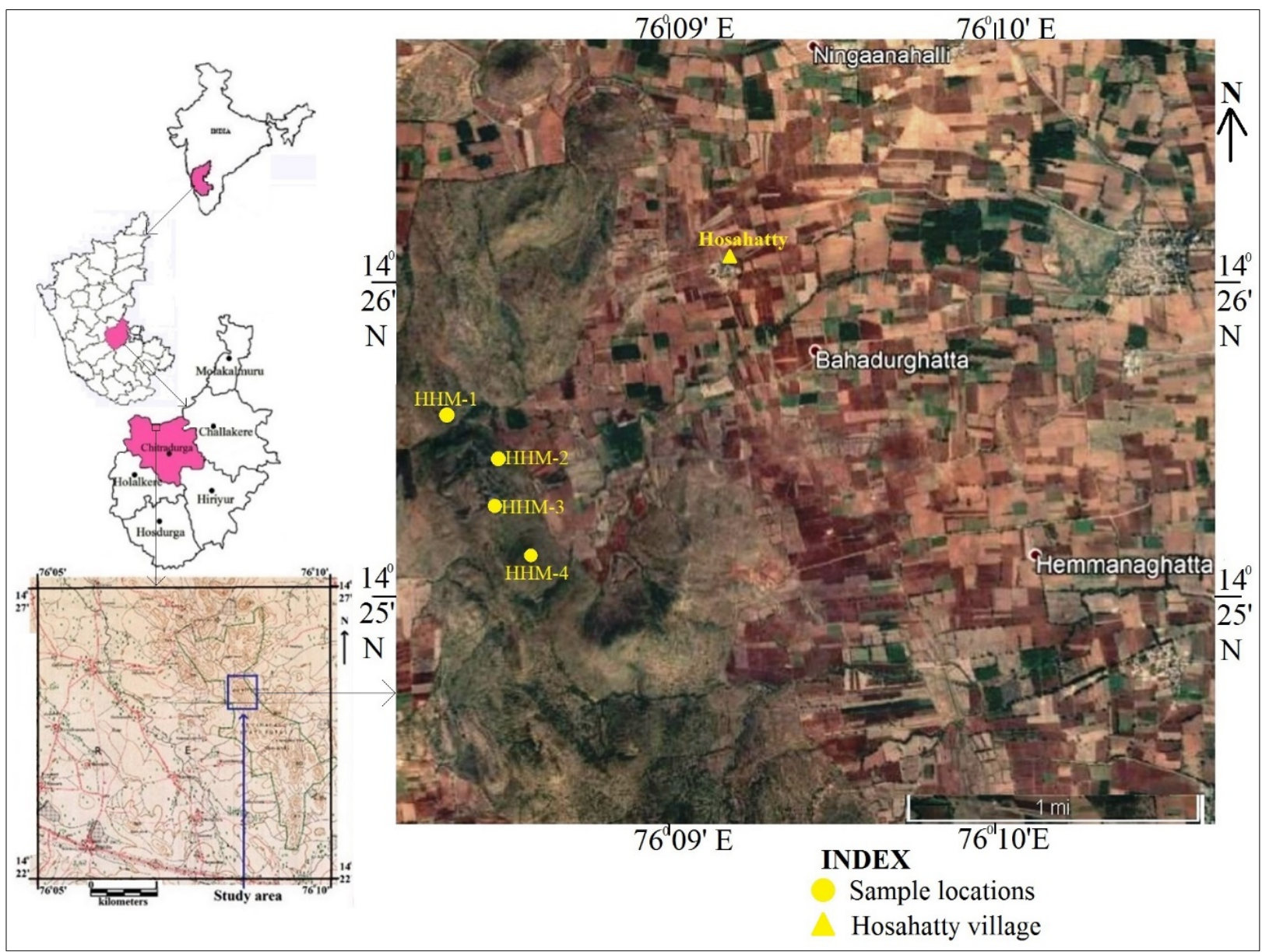

Figure 1. SoI Toposheet and Google earth image shows the location of the study area

2.2 Methodology: In this study, the reflectance spectra of four field samples are measured at the laboratory of Geological Survey of India, Bangalore using Analytical Spectral Devices (ASD) FieldSpec3 Spectro-radiometer (350-2500nm) (Basavarajappa et al, 2015). The obtained data are studied using ASD ViewSpec Pro software. The output is exported to ASCII format for further studies using Environment for Visualizing Images (ENVI) 4.6 software (Basavarajappa et al, 2017; Rajendran and Nasir, 2014). The spectra are used as an end member for detailed analysis and interpretation, and compared with the spectral library such as USGS, JPL and JHU available in the ENVI software (Nisha rani et al, 2014).

\section{RESULTS AND DISCUSSION}

3.1 Regional traverses along Halekal band, Bhahaddurghatta-Hosahatti village: The Chitradurga Schist Belt is represented by a thick pile of volcanic flows and sediments, iron and manganese ore formations occur in both off shore volcano-sedimentary sequence as well as in plat formal sedimentary sequence (GSI, 1981). The Halekal band is an outlier of Bababudan Group occurring to the north-east of Mayakonda belt between Bharamsagara and Anaji (GSI, 1981). It is mainly made of mafic platformal suite similar to Mayakonda belt but at the synclinal 
core manganiferous sediments are noticed. The manganese formations represent the lower portions of Chitradurga Group associated with polymictic conglomerate, dolerite dyke, actinolite-tremolite schist, auriferous quartz (gold bearing), quartz viens (lepidolite bearing). These dolerites are rich with clouded feldspars which could be due to effects of regional thermal metamorphism (GSI, 1981). The manganese ore is of magmatic type, where ores have undergone supergene enrichment type of volcanogenic origin which is simple with ore which shows pyrolusite, psilomelane and cryptomelane textures (GSI, 1981). Field investigation and petrographic determination represents that these are of fissure filling deposits type. The Halekal belt shows amphibolite facies metamorphism at the borders and green-schist facies at the core. Manganese mineralization is confined to manganiferous chert and phyllite in the study area (Seshadri et al, 1981). The uniformity in the composition of the manganese-rich bands and the co-folded nature of the manganese-bands indicated metasedimentary origin. Presence of manganite, pyrolusite, psilomelane and rhodochrosite in the manganese ores of supergene origin from the study area (IBM, 2014). Chadwick et al., (1981) proposed that manganese mineralization is present as disseminations of pyrolusite in metasedimentary ores.

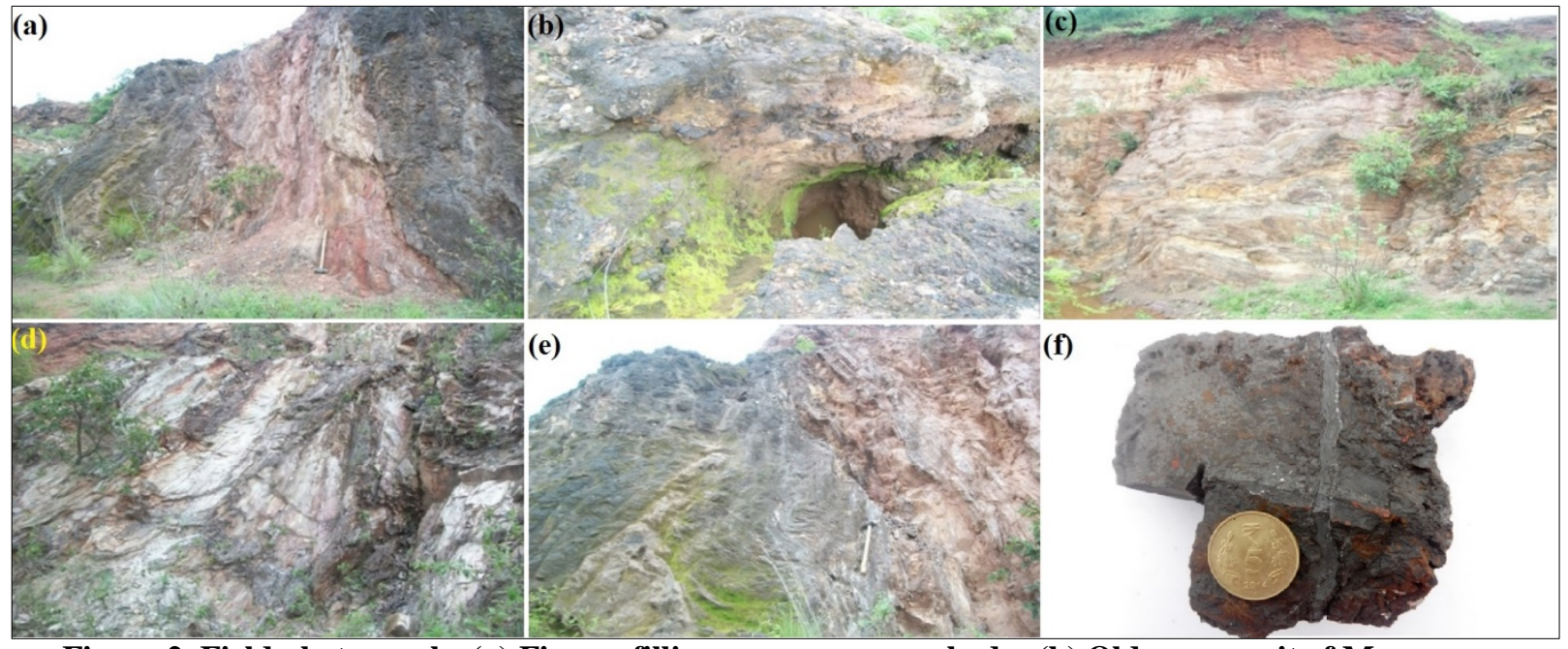

Figure 2. Field photographs (a) Fissure filling manganese ore body; (b) Old quarry pit of Manganese concentration; (c) Goethite-iron deposits; (d) Pinching and swelling of manganese concentration; (e) Manganese as fissure filling deposits; (f) A bulk sample of Manganese rich

3.2 Petrography \& Geochemistry: Representative manganese ore samples are collected from parts of Halekal band of Bhahaddurghatta-Hosahatty village and carried to the laboratory for petrography and chemical analysis using Atomic Absorption Spectrophotometer (AAS) additionally the major and trace elements. Manganese is formed by the reaction of water and carbon-di-oxide (Manjunatha, 2017). Manganeferous quartzites are observed at certain juncture (Fig.3a \& b). Quartz (Qtz) shows equigranular mineral grains in association with pyrolusite and psilomelane. The chemical analysis of four representative samples of manganese (Mn) ore ranges from $74-81 \%$, iron $\left(\mathrm{Fe}_{2} \mathrm{O}_{3}\right)$ ranges from $5-6 \%$ and silica $\left(\mathrm{SiO}_{2}\right)$ ranges from 4-7\%. Patel et al., (xx) had upgraded the manganese samples from $81 \%$ to $85 \mathrm{wt} \%$ by floatation technique at the $\mathrm{pH}$ of 7 ; whereas at the $\mathrm{pH}$ of 8 the same can be upgraded to $89 \mathrm{wt} \%$. 


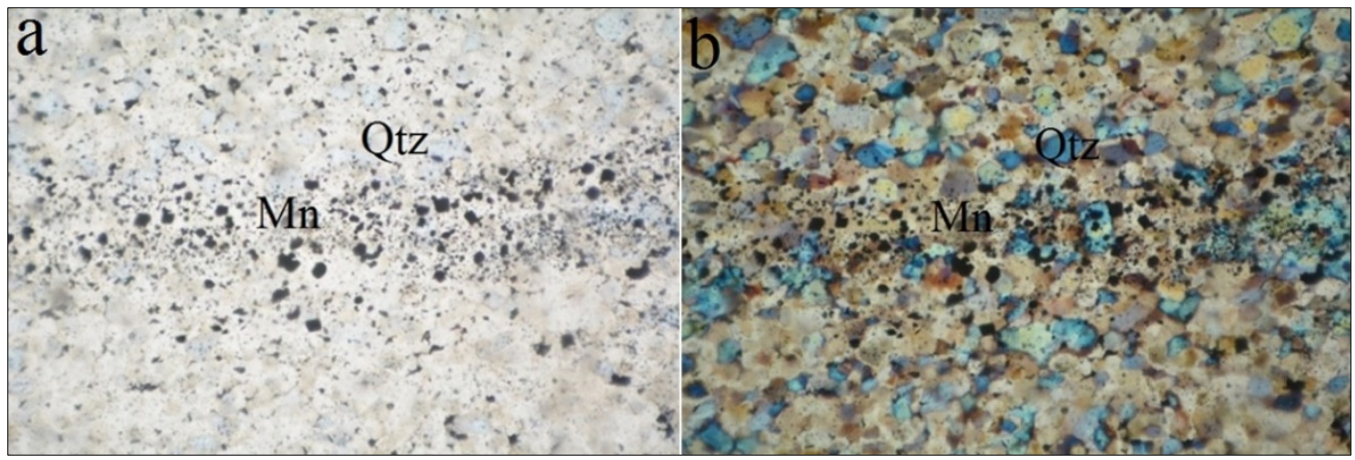

Figure 3. Photomicrograph of Manganeferous quartzite in (a) ppl-4x and (b) xpl-4x

3.3 Spectral Signatures Study: The lab spectra of pyrolusite minerals shows spectrally featureless, quite low reflectance, strong absorption throughout the entire visible $(0.3-0.7 \mu \mathrm{m})$ and reflective infrared (0.7 - $3 \mu \mathrm{m})$ spectral regions (Clark et al, 2003; Hunt and Salisbury, 1971; Hunt, 1977; Ibrahim et al, 2010) due to the presence of predominant Mn-O molecules. The minerals show weaker absorption features around 0.63 to $0.79 \mu \mathrm{m}$ due to the presence of pyrolusite with its chemical content. The metasedimentary manganese ores have been subjected to lateritization, which brought about changes in texture, mineralogy and its chemical composition. Further, lateritization caused dissolution of metasedimentary ores and consequent release of manganese and other metals to the circulating water $(1.44 \mu \mathrm{m}$ and $1.9 \mu \mathrm{m})$. The absorption features of iron oxide around 0.56 and $0.97 \mu \mathrm{m}$ due to presence of $\mathrm{Fe}^{3+}$ and $\mathrm{Fe}^{2+}$ in the samples. Hematite shows intense absorption feature in $0.55 \mu \mathrm{m}$ of the electromagnetic spectrum (Hunt and Salisbury, 1971; Manjunatha, 2017). Absorption anomalies at wavelength less than $0.9 \mu \mathrm{m}$ is a good indicator and shows strong absorption representing hematite presence (Basavarajappa et al, 2015). The diagnostic characteristics of manganese carbonate, namely rhodochrosite $\left(\mathrm{MnCO}_{3}\right)$ shows strong absorption features in the visible regions $(0.3-0.7 \mu \mathrm{m})$ due to the $\mathrm{Mn}-\mathrm{O}$ bonds and sharp absorption near $2.33 \mu \mathrm{m}$ in the infrared region due to the C-O bonds (Abrams et al, 1988; Mars and Rowan, 2010; Rajendran and Sobhi Nasir, xx; 2013b) occurred in its contents.

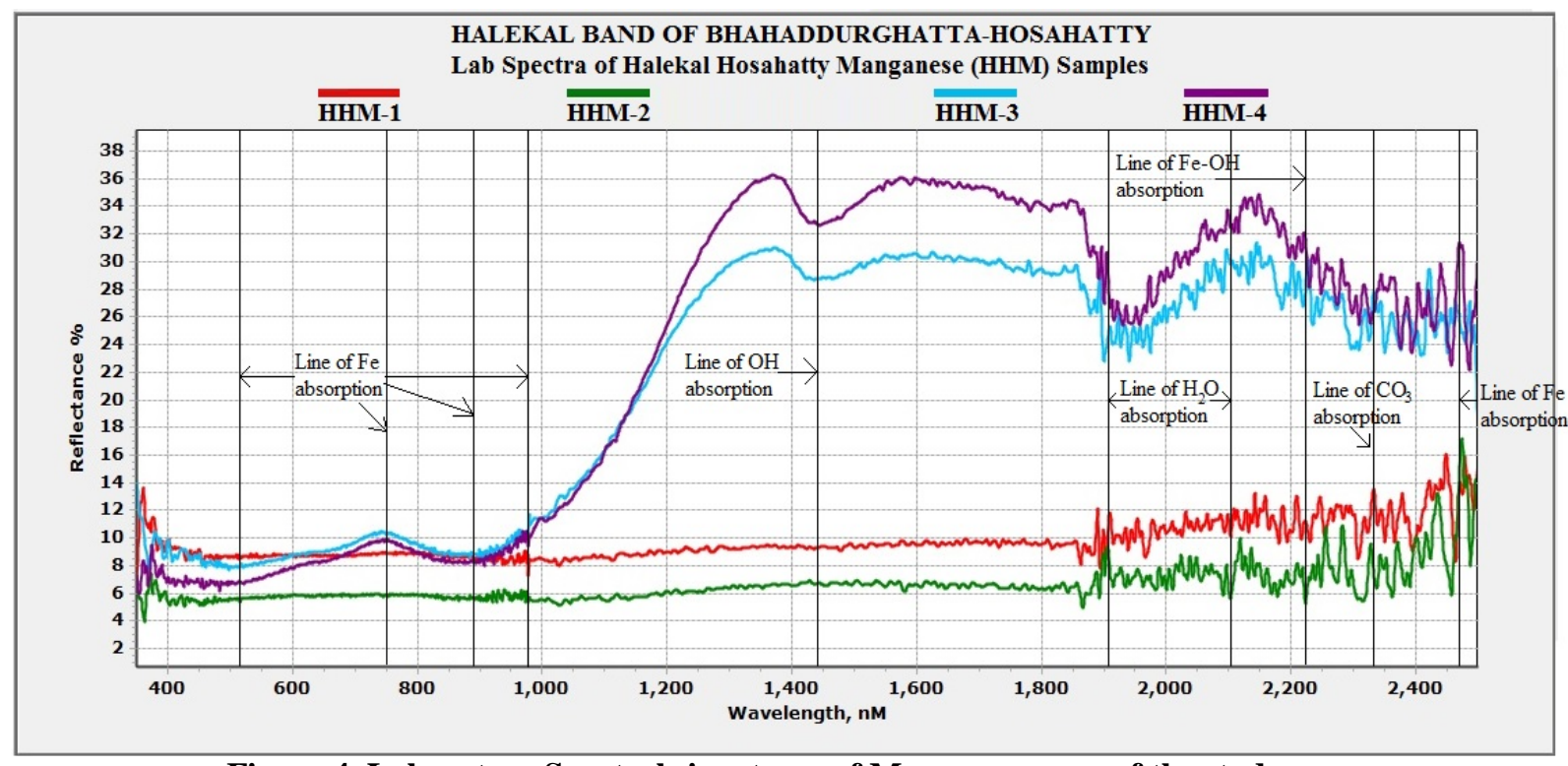

Figure 4. Laboratory Spectral signatures of Manganese ores of the study area 
Table.1. Major Elements and Spectral analysis data of the samples of the study area

\begin{tabular}{|c|c|c|c|c|c|}
\hline \multirow{2}{*}{\multicolumn{2}{|c|}{ Chemical constituents }} & \multicolumn{4}{|c|}{ Manganese Samples } \\
\hline & & HHM-1 & HHM-2 & HHM-3 & HHM-4 \\
\hline \multirow{12}{*}{ Elements (wt\%) } & $\mathrm{SiO}_{2}$ & 7.12 & 6.32 & 8.31 & 7.03 \\
\hline & $\mathrm{Al}_{2} \mathrm{O}_{3}$ & 0.30 & 0.21 & 0.24 & 0.29 \\
\hline & $\mathrm{BaO}$ & 0.65 & 0.72 & 0.78 & 0.74 \\
\hline & $\mathrm{TiO}_{2}$ & 0.11 & 0.08 & 0.07 & 0.10 \\
\hline & $\mathrm{Fe}_{2} \mathrm{O}_{3}$ & 6.32 & 7.12 & 8.31 & 9.39 \\
\hline & $\mathrm{MnO}$ & 81.39 & 80.01 & 74.25 & 77.44 \\
\hline & $\mathrm{MgO}$ & 0.36 & 0.23 & 0.32 & 0.29 \\
\hline & $\mathrm{CaO}$ & 0.13 & 0.09 & 0.11 & 0.07 \\
\hline & $\mathrm{K}_{2} \mathrm{O}$ & 0.11 & 0.08 & 0.01 & 0.09 \\
\hline & $\mathrm{P}_{2} \mathrm{O}_{5}$ & 0.02 & 0.02 & 0.01 & 0.02 \\
\hline & $\mathrm{H}_{2} 0^{+}$ & 3.12 & 2.29 & 4.93 & 3.45 \\
\hline & Total & 98.83 & 97.97 & 97.34 & 98.91 \\
\hline \multicolumn{6}{|c|}{ Spectral Analysis } \\
\hline $\begin{array}{c}\text { Absorption spectra } \\
(\mu \mathrm{m})\end{array}$ & $\begin{array}{l}\text { Lab spectral } \\
\text { signature }\end{array}$ & Psilomelane & Psilomelane & Pyrolusite & Pyrolusite \\
\hline Best matches to & USGS & Psilomelane & Psilomelane & Pyrolusite & Pyrolusite \\
\hline
\end{tabular}

Note: HHM- Halekal Hosahatty Manganese

\section{CONCLUSIONS}

The study shows that the spectral absorptions features depends on the major elemental composition or mineral constituents of the samples. The manganiferous quartzite sample show weaker absorption features around 0.63 to $0.79 \mu \mathrm{m}$ and 0.93 to $1.11 \mu \mathrm{m}$ due to the presence of pyrolusite with chemical content; while rhodochrosite shows sharp absorption near $2.33 \mu \mathrm{m}$ in the infrared region due to the $\mathrm{C}-\mathrm{O}$ bonds. The origin and concentration of manganese deposits in the study area show very rich in Mn content. The geochemical anomaly shows structurally controlled with fissure filling deposits and deep magmatic origin-syngenetic with higher concentration i.e., more than $81 \%$ which is highest in the Indian continent. The consumption rate of manganese is reaching critical stage and newly identification of high grade deposits are very much necessary for future needs and sustainability. The $\mathrm{MnO}_{2}$ content in BhahaddurghattaHosahatty village is most appreciable due to its highest percentage content in India with $81 \%$ which is most suitable for proper mining exploration and industrial utilization.

\section{Acknowledgement}

The authors indepthly thank to Prof. P. Madesh, Chairman, DoS in Earth Science, CAS in Precambrian Geology, Univ. of Mysore, Mysore; Prof. Y.T. Krishne Gowda, Principal, Maharaja Institute of Technology Thandavapura, Mysuru.

\section{REFERENCES}

1. Abrams M.J, Rothery D.A, Pontual A, "Mapping in the Oman Ophiolite using enhanced Landsat Thematic Mapper images”, Tectonophysics, vol.151, (1988), pp. 387-401.

2. Ali Mohammed Qaid Saeed, "Application of Remote Sensing and GIS techniques in mapping of hydrothermal alteration zones in North East Hajjah, Yemen", Unpub thesis, University of Mysore, (2008), pp. 1-237.

3. Basavarajappa H.T, Manjunatha M.C and Rajendran S, "Integration of Hyperspectral Signatures and Major elements of Iron ore deposits around Holalakere range of Megalahalli, Chitradurga Schist Belt, Karnataka, India”, The Indian Mineralogist, vol.49, no.1, (2015), pp. 85-93. 
4. Basavarajappa H.T, Manjunatha M.C, Rajendran S and Jeevan L, "Determination of Spectral Characteristics on Archaean Komatiites in Ghattihosahalli Schist Belt (GSB) of Kumminagatta, Chitradurga District, Karnataka, India”, International Journal of Advanced Remote Sensing and GIS, vol.6, issue.1, (2017), pp. 2416-2423.

5. Chadwick B, Ramakrishnan M. and Viswanatha M.N, "Structural and metamorphic relations between Sargur and Dharwar supracrustal rocks and peninsular gneiss in Central Karnataka”, Journal of the Geological Society of India, vol.22, (1981), pp. 557-569.

6. Clark R.N, Swayze G.A, Wise R, Livo K.E, Hoefen T.M, Kokaly R.F, Sutley S.J, "USGS Digital Spectral Library splib05a”, U.S. Geological Survey, (2003), Open File Report 03-395.

7. GSI - Memoir, "Early Precambrian Supracrustals of Southern Karnataka”, Geological Survey of India, Govt. of India, vol.112, (1981), pp. 163-198.

8. Hunt G.R, Salisbury J.W, "Visible and near-infrared spectra of minerals and rocks: II. Carbonates", Modern Geology, vol.2, (1971), pp. 23-30.

9. Hunt G.R, Salisbury J.W and Lenhoff C.J, "Visible and Near-infrared Spectra of minerals and rocks”, IV. Sulphides and sulphates, Mod. Geol, vol.3, (1971), pp. 1-4.

10. Hunt G.R, "Spectral signatures of particulate minerals in the visible and near infrared, Geophysics, vol.42, (1977), pp. 501-503.

11. IBM, "Indian Bureau of Mines, Market Survey on Manganese ore", Ministry of Mines, Govt. of India, (2014), pp. 1-225. http://ibm.nic.in/writereaddata/files/07142014124825Market\%20Survey Manganese\%20Ore.pdf

12. Ibrahim A. Salem Mohamed E. Ibrahim. Mohamed Abd El Monsef, "Mineralogy, geochemistry, and origin of hydrothermal manganese veins at Wadi Maliek, Southern Eastern Desert, Egypt”. Arab J Geosci, (2010), DOI 10.1007/s12517-010-0195-1.

13. Jeevan L, "Application of Hyperspectral Remote Sensing and GIS techniques for mapping of hydrothermal alteration zones of Precambrian rocks in parts of Chitradurga Schist Belt, Dharwar Craton, India”, Unpub thesis, University of Mysore, (2018), pp. 1-250.

14. Manjunatha M.C, "Applications of Hyperspectral Remote Sensing and GIS on NE-SW transects of Chitradurga district, Karnataka, India”, Unpub thesis, University of Mysore, (2017), pp. 1-204.

15. Mars J.C, Rowan L.C, "Spectral assessment of new ASTER SWIR surface reflectance data products for spectroscopic mapping of rocks and minerals”, Remote Sensing of Environment, vol.114, (2010), pp. 2011-2025.

16. Mihir Deb and Gurmeet Kaur, "Earth processes and resources: Metallogeny", https://www. researchgate.net/publication/275770525 earth processes and resources Metallogeny (xx).

17. Nisha Rani, Sumit Kumar Ahirwar and Jamalanwar, "Hyperspectral Remote Sensing Studies of Mafic- Ultramafic rocks of Sargur and Bababudan Groups, Hassan district, Karnataka, South India”, The Indian Mineralogist, vol.48, no.2, (2014), pp. 239-248.

18. Patil M.R, Nijagunappa R, Prakash S, Dixit R.R and Somasekar B, "Studies on Suitability of high grade manganese ore of Bahadurgatta area, Chitradurga District, Karnataka in the manufacture of electrolytic manganese dioxide”, (xx). Pp: 84-87, http://eprints.nmlindia.org/4385/1/84-87.PDF

19. Rajendran $S$ and Sobhi Nasir S, "Mapping of manganese potential areas using ASTER satellite data in parts of Sultanate of Oman", International Journal of Geosciences and Geomatics, Arab Remote Sensing and Geographic Information System Organization, vol.x, (xx), pp. 92-101.

20. Rajendran S, Nasir S, Kusky T.M, Ghulam A, Gabr S. and Elghali M, "Detection of hydrothermal mineralized zones associated with Listwaenites rocks in the Central Oman using ASTER data”, Ore Geol. Rev., vol. 53, (2013a), pp. 470-488.

21. Rajendran S, Nasir S, "ASTER mapping of limestone formations and study of caves, springs and depressions in parts of Sultanate of Oman", Environ Earth Sci, (2013b), DOI 10.1007/s12665-0132419-7.

22. Rajendran S. and Nasir S, "Hydrothermal altered serpentinized zone and a study of Nimagnesioferrite-magnetite-awaruite occurrences in Wadi Hibi, Northern Oman Mountain: 
Discrimination through ASTER mapping”. Elsevier-Ore Geology Reviews, vol.62, (2014), pp. 211226.

23. Roy, S., “Manganese deposits”. Academic Press, London. (1981), 458p.

24. Seshadri T.S, Chaudhuri A, Harinadha Babu P, Chayapathi N, Chitradurga belt, "In: Swaminath J and Ramakrishna M (Eds), Early Precambrian Supracrustals of Southern Karnataka”, Geological Survey of India, Memoir-112, (1981), pp. 163-198. 